\title{
Crónicas do tempo suspenso
}

https://doi.org/10.21814/uminho.ed.23.13

\section{Ana Gabriela Macedo}

Ana Gabriela Macedo (ORCID: 0000-0001-7823-0613) é Professora Catedrática da Universidade do Minho, coordenadora do Programa Doutoral "Modernidades Comparadas. Literaturas, Artes e Culturas" e coordenadora do grupo de pesquisa em "Género, Artes e Estudos Pós-Coloniais” (GAPS) do Centro de Estudos Humanísticos da mesma Universidade. As suas áreas de investigação repartem-se pelo Modernismo, Pós-modernismo, Poéticas Visuais, Crítica Feminista e Estudos de Género. 


\section{CRÓNICA DO TEMPO SUSPENSO 1}

\section{Do espanto}

\section{Do medo}

Em Itália foi decretado o estado de emergência. Ninguém entra, ninguém sai do país. As famílias fechadas em casa, jovens, crianças, velhos.

O que fazem os italianos em Roma, a capital do país? Abrem as janelas de par em par, vêm para as varandas em família: bandeiras do país içadas, entoam canções populares, um jovem toca a sua guitarra, uma mulher canta uma área de ópera, enquanto o companheiro faz soar as cordas de um violino. Loucura colectiva? Não, uma partilha comovente de vida e de cidadania; formas simples, mas claras e positivas de viver no colectivo possível o momento da emergência, formas cidadãs de mostrar resiliência. E a recusa do individualismo, face ao pânico do apocalipse.

15 Março 2020

\section{CRÓNICA DO TEMPO SUSPENSO 2}

\section{Enquanto isso ...}

Enquanto isso ..., o tempo suspenso, este aguardar nesta espécie de estado de sítio - cozinhamos, comemos, lavamos a roupa desenfreadamente, lavamos as mãos e o corpo, meticulosamente, com uma atenção que nunca antes lhes dedicámos. Foi-nos dito que a nossa salvação reside aí, em primeira instância. Obedecemos, como nunca antes, cientes de um 'mal maior' invisível, desconhecido e, por isso mesmo, aterrador, que toma conta de nós, e nos invade sem que demos conta. As crianças perguntam a toda a hora, com espanto, 'por que não podemos ir brincar lá para fora? Por que não podemos ir ao encontro dos amigos? e os beijos? e os abraços? Onde estão todos eles?'

Difícil explicar, impossível absorver de repente toda esta realidade estranha que tomou conta de nós e se tornou no nosso quotidiano. De ontem para hoje, e dizem-nos não saber por quanto tempo, esta é a realidade de TODOS NÓS. Um 'nós' planetário, como não sabíamos ser possível existir - muito para lá de qualquer ficção científica, 
qualquer distopia ... Orwell, Huxley, Bradbury, Atwood, tornados profetas menores comparados com esta realidade assombrosa.

Enquanto isso ..., crianças crescem nos ventres redondos de jovens mães, jovens expectantes esperam pacientemente que o mundo siga o seu curso e o tempo suspenso cesse em limpa alvorada.

O que faremos então? Tentaremos esquecer rapidamente o pesadelo? Iludir, cobrir com um manto, camuflar este limiar de vida e não vida, onde horas, minutos e segundos passam a conta-gotas? Ou procurar alternativas, outros modos menos agressivos, menos excessivos de estar e de viver? ... O que aprenderemos nós? Se tivermos quiçá essa oportunidade.

5 Abril 2020

\section{CRÓNICA DO TEMPO SUSPENSO 3}

\section{'Escrever em tinta invisivel'}

Nunca os pássaros cantaram tanto, nunca o silêncio se fez ouvir com tanta intensidade. As cidades desertas, esparsos automóveis circulando, os autocarros passam, vazios, cumprindo a sua rota diligentemente, mas sem sentido. Cruzamo-nos fugitivamente com rostos assustados e sombras do que foram os habitantes da cidade, vizinhos ou até amigos, um aceno de mão, um esboço de sorriso. É tudo do que somos capazes. $\mathrm{O}$ relógio parou, por assim dizer. Sabemos vagamente que hoje é 3aㅡ, $4^{\underline{a}}$ ou $5 \underline{a}$ feira, mas isso em pouco se traduz. Sabemos, porém, a hora dos noticiários, fitamos a televisão mudos e expectantes. A esparsos momentos circulam nas ruas carros das forças de segurança repetindo incansavelmente num tom, que não é ameaçador, mas que destila o medo e a ansiedade que nos habitam: 'Estar em casa', 'Não saiam à rua', 'Distância social'. Palavras cujo significado não apreendemos de imediato, de tal modo elas são alheias e contrárias ao nosso quotidiano de seres urbanos, vivendo em colectivo, profissionais, pais, mães, jovens ou idosos. As igrejas estão fechadas. Crianças ergueram cruzes nos seus minúsculos jardins de cidade e enfeitaram-nas de flores e um pano branco. A nossa Páscoa possível. Uma grande sombra nos impede de ver o sol, gozar a luminosidade 
desta Primavera de 2020, que não terá igual. Muitos procuram as palavras certas para a descrever. Difícil, quase impossível, dizem escritores, poetas ou mesmo políticos. Ouve-se, 'estamos em guerra', repetidamente. Generalizam-se termos, em frases paradoxais, a que nos vamos habituando, repetindo-as um pouco como robots: 'abraço com distância'; 'vamos ficar bem'. Despedimo-nos de amigos, conhecidos e colegas de trabalho, em emails, com uma saudação antiga, há muito caída em desuso, hoje reinventada: 'Saúde!'. A cozinha tornou-se a nossa 'sala de estar', o nosso refúgio e um dos únicos possíveis locais de partilha: inventamos receitas, vasculhamos livros velhos de culinária de outros tempos, com a caligrafia desenhada das avós, em busca de algo que nos dê a ilusão de realidade, alegria, prazer, pertença. Redescobrimos que comer é muito mais do que cumprir uma necessidade física, é saborear, é, como bem sabemos, rememorar: tempos, episódios, situações de vida. Por isso muitas vezes fechamos os olhos quando saboreamos algo realmente muito bom, ou muito diferente. Em busca de ... algo ou alguém com quem partilhar essa rememoração, esse sabor. Fotografias, vídeos, mails e twitters, preenchem vorazmente o nosso quotidiano. Mas agora, é também o passado que buscamos, uma vida anterior, o tempo outro em que o relógio não tinha parado.

'O meu futuro está no meu passado', escreveu a poeta Anna Akhmatova na epígrafe de 'O Inverso' ('Obverse', na belíssima tradução em língua inglesa de D.M. Thomas), Parte II do seu famoso Poema sem Herói (tríptico, 1940-1962). Poema sobre a cidade de Leninegrado sitiada pelo terror estalinista, e evocação de uma outra cidade, Londres nos anos 1940, sitiada pela guerra, evocada no poema 'Quatro Quartetos' de T.S. Eliot, a quem a poeta pediu de empréstimo a epígrafe acima. 'Escrever em tinta invisivel' é o 'crime' que a poeta russa se sente capaz de cometer, nesse momento histórico outro de medo, angústia e vida suspensa.

Procuramos hoje todos nós palavras para dizer de um modo possível, não banal, pleno de sentimento, o paradoxo que vivemos, a sombra que se abateu sobre nós, a impossibilidade de viver esta Primavera surpreendentemente luminosa. Como diz a poeta, é como se 'um anjo tivesse tropeçado na sua ascensão ao céu'...

19 Abril 2020 


\section{CRÓNICA DO TEMPO SUSPENSO 4}

\section{'Sem dias de solidão'}

Retomamos a vida como se ... tudo fosse normal. É a única forma que temos de enfrentar o quotidiano. Muita coisa mudou contudo. $\mathrm{O}$ ser humano adapta-se. Sobreviver é uma arte ancestral. E somos mestres nisso. Descobrimo-lo, melhor, redescobrimo-lo.

$\mathrm{Na}$ televisão a pergunta constante aos entrevistados, artistas, políticos, economistas, é esta: 'qual é a primeira coisa que vai fazer 'quando isto acabar'? ('Isto' é aquilo que não tem nome. A doença invisível e o medo dela.) Invariavelmente, a resposta é: 'Vou correr a abraçar e beijar a minha família, os meus amigos, aqueles que são a minha vida'. Ninguém tem constrangimento em expor assim as suas emoçốes mais íntimas - a necessidade do toque, a proximidade do corpo dos que amamos, o calor do seu abraço e do seu rosto próximo. Dizem-se coisas na televisão que jamais pensaríamos ouvir publicamente expostas: 'o prazer de fazer a cama do meu filho pequeno', dizia um jornalista homem, com um sorriso comovido em pleno Telejornal. O tempo e os nossos mais triviais actos quotidianos assumiram uma outra forma, uma nova dimensão, adquiriram um novo significado.

Na rua, nos tais 'breves passeios higiénicos permitidos', cruzamo-nos amiúde com gente que não conhecemos, que nunca vimos, passeantes como nós, escapando por alguns minutos da reclusão. Como catraios, em fuga clandestina. E cumprimentamo-nos quase efusivamente, como velhos conhecidos, humanos que todos somos, sobreviventes, por assim dizer. Em plena cidade, um velho gesto recuperado do tratamento nas aldeias, onde todos se conhecem. É como se ... nesse gesto amigável houvesse mais do que simples cortesia, o gosto em ver o outro vivo e de saúde, e regozijarmo-nos francamente com isso, dizendo sem palavras, 'Gosto em vê-lo. Eu também estou bem obrigada!'.

E nunca os portugueses demonstraram tanto sentido de humor, tanta ironia fina como forma de resistência às horas solitárias deste novo quotidiano. Talvez a melhor designação entre as que tenho encontrado seja esta: 'Sem dias de solidão'. Chegou-me por mail das sessóes do Teatro do Campo Alegre, no Porto, as antigas Quintas de Leitura, assim rebaptizadas. Muito mais poético, sem dúvida! E isto acontece frequentemente, a reinvenção da palavra, novos sentidos e novas sintaxes para dizer 'de outro 
modo' aquilo que é/era o nosso mundo e a nossa vontade teimosa de o viver, apesar de tudo, com alegria e sem dias de solidão ... Espantamo-nos a toda a hora com tanta criatividade, tanta partilha espontânea, tanto desejo de colectividade - a música, o teatro, os museus, os artigos de jornais e revistas de arte, em casa, no sofá, na cozinha (o lugar da casa tornado agora, por força da necessidade, favorito, talvez por sempre ter sido o mais imprescindível). Redescobrimos a cada dia que passa, o porquê da 'cidade', não como um aglomerado indistinto e anónimo de casas, mas, digo-o com esperança, da cidadania, da vivência colectiva. Não é de uma 'guerra' que se trata, por muito que os comentaristas mais apocalípticos o repitam no telejornal, mas de uma genuína revolução (ética?), uma mudança de paradigma civilizacional, um novo pós-, pós-, pós-, ainda indeterminado. Estamos, sem dúvida, ainda em plena busca do substantivo certo para juntar ao prefixo.

15 Maio 2020

\section{CRÓNICA DO TEMPO SUSPENSO 5}

\section{A 'linha da frente'}

Neste quotidiano de tempo dilatado, nós, os professores, somos talvez os menos ociosos, horas a fio diante do computador a desbravar plataformas, o Zoom, o collaborate, o blackboard, e por aí fora! Livros empilhados nas nossas (outrora) salas de jantar ou salas de estar, agora, como dizia uma colega com muita graça, transformadas em 'salas de aula, biblioteca, recreio, e até esplanada'.

Como quase sempre deles (de nós), fala-se pouco. Estamos sim, na linha da frente. Sem sombra de dúvidas. Não curamos feridas nos corpos, não colocamos ventiladores e máscaras de oxigénio, mas sujamos as mãos continuamente segurando as mãos dos jovens e das crianças diante de quem todos os dias nos sentamos, cara alegre, banho tomado, cabelos alinhados, perfumados até, para discutir 'O Crime do Padre Amaro' ou 'A Fada Azul', ou mesmo 'Os Lusíadas', ou o passé simple e o passé composé, os malvados dos 'phrasal verbs', ou quiçá as conjunções adversativas e copulativas...! 
E os miúdos tontos de sono, inquietos e espantados ainda com a nova ordem das coisas que os impele agora a sentar horas a fio diante do computador, ou da televisão, infelizmente sem ser para fazer videogames!

Mas o mais estranho de tudo é que os jovens estudantes de facto colaboram! Não faltam às aulas (lá está a mãe para dar dois gritos e pô-los da cama para fora ...) e sem querer idealizar a questão, mas pelo que me é dado ver e viver, professora que sou, dedicam-se a fazer excelentes powerpoints, como nunca antes, enviam diligentemente os ensaios pedidos para professores e colegas. Constato o facto, e com imenso regozijo. Será que as aulas 'dadas à distância' são menos 'chatas'? será que os jovens, mesmo os mais pequenos, sentem a responsabilidade do tempo presente que também não os poupou, crianças que são? O que é certo é que as coisas funcionam! E perguntem às mães sobretudo, o que fariam sem estas horas de aulas em que s filhos estão entregues (virtualmente ou não, pouco importa) aos professores! Atrevo-me a dizer, psicóloga que não sou (e curiosamente psicólogos e sociólogos têm estado muito silenciosos neste país, estranhamente, a meu ver), dizia, é o momento do colectivo também para estes jovens, o espaço possível de rever, mesmo sem poder tocar, colegas e amigos, trocar ideias, sentir que o tempo flui numa quase 'normalidade'. Com tpc e avaliaçôes para cumprir!

Episódios divertidos acontecem a todo o momento: um dia é o gato da casa que se consegue escapulir e passeia desavergonhadamente em frente ao ecrã, pisando as teclas do computador e criando o caos! Outro dia é o cão do vizinho que ladra e não se pode ir lá bater à porta e exigir silêncio, cortesmente ou aos berros. Outras vezes é um telefonema trágico que interrompe a aula, um familiar que foi internado ou pior ainda.

E nós, professores, pegamos nas mãos deles, creio que não só virtualmente, e dizemos fazendo das tripas coração: 'Vamos lá, malta, quero ainda ouvir-vos falar hoje da insubordinação contra a ética vitoriana na Jane Eyre de Charlotte Brontë!'.

Não estaremos nós na linha da frente?

7 Maio 2020 


\section{CRÓNICA DO TEMPO SUSPENSO 6}

\section{Em bomenagem a Maria Velbo da Costa}

Myra disse a Rambo,

A ver se não caímos em cima de ninguém.

O cão, aterrado, disse,

Tem de ser?

Myra disse,

Tem de ser.

Myra puxou uma cadeira para junto do beiral, largo, da janela, debruado a granito, a fazer novo-rico. Como se os novo-ricos não tivessem direitos. Mas ela não tinha.

Morria de artista, à russa, e com ela um cão, que de qualquer das formas, estava condenado. Sentou-se no rebordo da janela, de costas, e chamou o cão para a cadeira.(...) Myra tomou-o nos braços e atirou-se para trás, como um mergulbador equipado se atira de um barco de pesquisa submarina. Rambo ainda se debateu nos braços dela, na queda, mas eram já asas.

[(extracto de Myra, de Maria Velho da Costa (Assírio e Alvim, 2008) p.221)]

Foram muitos os escritores, artistas, cientistas que faleceram durante a quarentena da pandemia, entre Março e Maio de 2020. Uns por morte directamente derivada da infecção viral, outros de morte natural (estranho modo de dizer a morte, mas a que nos vamos habituando também). Porém todos foram igualmente vítimas da singularidade do momento presente: a impossibilidade da celebração última das suas vidas, junto daqueles que a testemunharam, beneficiaram da sua experiência, generosidade, sabedoria ou arte. Familiares e amigos viram-se obrigados a chorar a sua dor em silêncio, na impossibilidade dessa manifestação derradeira de afecto e reconhecimento. 
Evoco no longo rol dos desaparecidos nesta estranha Primavera de 2020, duas mulheres: Maria de Sousa, a eminente cientista portuguesa, reputada pela sua longa e influente carreira internacional como imunologista, e pelo seu papel como pedagoga e dinamizadora das ciências da vida em Portugal. Outros mais conhecedores do que eu da sua obra científica, saberão render-lhe a homenagem merecida.

E Maria Velho da Costa, a escritora contemporânea portuguesa a meu ver mais fulgurante e impossível de catalogar. Exímia na arte do romance - a palavra em diálogo -, na representação acerba do real, particularmente através da cosmovisão das mulheres, e na criação de uma linguagem intrépida e vibrante. Maria Velho da Costa faleceu a 23 de Maio de 2020, deixando um vazio difícil de traduzir em palavras. Por uma dessas improváveis coincidências, o seu romance de 2008, Myra, que foi o seu último romance, como a própria vaticinara, foi estudado e debatido nas minhas aulas de Literatura Comparada na semana anterior à sua morte. Como uma homenagem antecipada, disse-me depois, sentidamente, um dos alunos. Nenhum ficou imune à densidade da sua palavra, à riqueza polifónica das várias línguas e linguagens que o seu texto explora e às quais dá corpo e espessura. A comovente relação amorosa, expressa numa língua outra que não a humana, entre a jovem protagonista Myra (russa? ucraniana?, 'do Leste', como ela sucintamente se diz no romance), também auto-denominada Kate, Katerina, Sónia ou Sophia, consoante o momento e o contexto assim o pediam (o nome sempre cobrindo a sua verdadeira identidade, esta nunca exposta, por medo, por necessidade de sobrevivência ou quiçá indiferença dos demais), e o seu cão Rambo, depois Rambô (lido Rimbaud como o nome do poeta-vidente francês), a quem ela gostaria de ter chamado Tzar, ficando-se contudo por um mais prosaico denominativo, César. Porque 'um nome é um destino' (p.33), diz-se no texto - 'Rambo é carne da minha carne. Rambo sou eu', diz a jovem para si mesma (p. 119). Myra é, tal como o seu cão, um animal acorrentado e escorraçado, violento por força das circunstâncias e impossível de domesticar. $\mathrm{O}$ animal é o único ser vivo que a acompanha na vida errante que tem e até no momento último da sua morte voluntária - o suicídio com que recusa integrar o circuito de prostituição em que se vê envolvida.

A escolha da morte é assim o acto último, a um tempo regenerador e libertador que cumpre, recusando sempre o papel de vítima, assumindo-se como protagonista 
até no desenlace do seu próprio drama. Ouvimos a sua voz através da fala cúmplice da narradora. A jovem 'todos-os-nomes' é aqui ela mesma, e todas as outras que sofreram/ sofrem um destino semelhante:

Myra disse a Rambo,

A ver se não caímos em cima de ninguém.

Ocão, aterrado, disse,

Tem de ser?

Myra disse,

Tem de ser.

23 Maio 2020

\section{CRÓNICA DO TEMPO SUSPENSO 7}

\section{Regresso ao Futuro}

\section{(O concerto de Miguel Araújo em Caminha)}

Foi o primeiro concerto pós-quarentena, ainda em tempo suspenso, com máscara e lugares marcados a 1,5m de distância entre o público. Uma palavra antipática a que nos vamos, a custo, habituando.

O minúsculo teatro de Caminha, o teatro Valadares, esgotou rapidamente para o concerto de Miguel Araújo. Foi assim transformada a Praça Calouste Gulbenkian, em pleno coração da belíssima vila, num auditório improvisado ao ar livre, dispondo de um ecrã gigante e um público atento e, tenho a certeza que não exagero se disser, emocionado.

Foram 21 concertos realizados na mesma noite, a noite do solstício de Verão, a noite mais breve do ano, celebrando um esperançado 'regresso ao futuro', nas cidades de Norte ao Sul do país. Caminha foi, enquanto vila, a única que participou, talvez pela força da sua beleza geográfica, da sua situação privilegiada, de frente para o 
magnífico estuário do rio Minho, estabelecendo uma fronteira líquida com a Galiza, face ao imponente monte de Santa Tecla, uma fronteira líquida que é também uma ponte de intercâmbio permanente.

Foi um espetáculo comovente, porque todos, músico, trabalhadores do som e das luzes, e público, estávamos a fruir o mesmo momento, traduzindo o mesmo desejo: a partilha da música, o cantar em conjunto canções de todos conhecidas e que fizeram o nosso quotidiano; porque a experiência de as ouvir, trautear, assobiar em colectivo é incomparavelmente melhor, mais saborosa, mais íntima, por paradoxal que pareça, do que em solidão ou isolamento. E ainda porque, e este é um ponto fulcral na organização destes Concertos chamados o Regresso ao Futuro, os bilhetes adquiridos, quer para o espaço do Teatro Valadares, quer para a Praça Calouste Gulbenkian, eram retribuídos não monetariamente, mas com uma contribuição em 'géneros alimentares não perecíveis', destinados a serem 'recolhidos e distribuídos pela União Audiovisual dos profissionais do Sector das Artes’. A Cultura em situação de vulnerabilidade. Esta é uma das feridas abertas da quarentena, longe ainda de poder cicatrizar.

Cientes desta vulnerabilidade, que nos afecta a todos, que é de todos nós, o concerto do solstício de Verão em 20 Junho 2020, foi um solidário 'regresso ao futuro' partilhado com alegria, mas foi também um regresso emocionado e emocionante. Pessoalmente, quero ainda dizê-lo, foi a alegria de festejar o primeiro concerto da minha neta Inês, ainda na barriga da sua mãe.

Oxalá o futuro não tarde. Foi o que as palmas do público quiseram dizer. 21 Junho 2020

\section{CRÓNICA 8 DO TEMPO SUSPENSO ... ainda!}

\section{O 'novo normal' [novonormal]}

Como definir gramaticalmente esta expressão inusitada? Define um estado, ou uma situação de facto, não é uma mera adjectivação circunstancial. Será palavra composta por justaposição? Se assim fora, cada elemento lexical (juntos por hífen) manteria a sua integridade e o seu significado primeiro, tal como 'beija-flor' ou 'peixe-espada', 
por exemplo. Por aglutinação, sem ser o reverso, implica uma união mais profunda entre os dois termos, que os torna indissociáveis numa nova significação, traduzindo uma nova realidade. Isto que digo não é de todo verdade, que me perdoem linguistas e estudiosos de sintaxe e semântica, apenas uma intuição de quem se habituou desde pequena a 'pensar palavras' e procurar-lhes os sentidos ocultos ou latentes, como diz o poeta de Voyelles. Ainda não há (para já! ...), digamos, uma perda de 'integridade silábica' ou a existência de uma 'acentuação única' neste novo lexema composto, mas indubitavelmente deixámos já de sentir a estranheza inicial que provocava em nós ouvir a dita expressão, na tentativa de traduzir e atribuir significância ou espessura linguística, à realidade difusa, incerta, insegura, inóspita que vivemos. Cientes da carga paradoxal contida no neologismo, necessitamos como humanos que somos de descrever o nosso mundo hoje, feito da obrigatoriedade de máscaras, de gel desinfectante ubíquo, da impossibilidade de ajuntamentos (mais de quatro pessoas!), de 'distância social' (outra quase impossibilidade e contradição em termos). Em suma, como dizer em palavras a vida virtual a que nos vamos, por força, habituando, sobreviventes que somos. $\mathrm{O}$ 'novo normal' [novonormal] di-lo, sem o dizer.

Ciente do tom um pouco desconcertante desta crónica, transcrevo aqui, em jeito de esperança, as palavras sábias da escritora norte-americana Toni Morrison, primeira mulher negra a ganhar um Nobel da Literatura (1993):

"O labor da palavra é sublime, porque produz sentidos que reconhecem a nossa diferença - a nossa diferença bumana - aquela que nos torna distintos de qualquer outra forma de vida. Morremos. Talvez seja esse o sentido da vida. Mas criamos linguagem. Talvez seja essa a medida das nossas vidas"(Toni Morrison, in 'Discurso do Nobel')

8 Outubro 2020 